\title{
Circulating human leucocyte elastase in patients with inflammatory bowel disease
}

\author{
E O ADEYEMI, S NEUMANN, V S CHADWICK, H J F HODGSON, AND \\ M B PEPYS
}

From the Gastroenterology Unit, and the MRC Acute Phase Protein Research Group, Immunological Medicine Unit, Department of Medicine, Royal Postgraduate Medical School, Hammersmith Hospital, London, and E Merck, D-6100 Darmstadt-1, Federal Republic of Germany

SUMmaRY The plasma concentration of human leucocyte elastase (HLE), measured by enzyme immunoassay as the complex with $\alpha_{1}$-proteinase inhibitor, was determined in 94 patients with active and inactive inflammatory bowel disease. In Crohn's disease and in ulcerative colitis human leucocyte elastase levels were raised significantly above normal when the disease was active, and fell on remission. The mean human leucocyte elastase level in 31 cases of active Crohn's disease was significantly greater than the mean human leucocyte elastase level in 23 patients with active ulcerative colitis $(p=0 \cdot 013)$. The values of human leucocyte elastase correlated significantly with Crohn's disease activity index scores $(p=0.05)$ and with the circulating concentration of C-reactive protein $(\mathrm{p}<0.05$ and $\mathrm{p}<0.01$ for ulcerative colitis and Crohn's disease respectively), but not with the erythrocyte sedimentation rate. These results indicate that the concentration of human leucocyte elastase in the plasma of patients with inflammatory bowel disease reflects the activity of their intestinal disease and suggest that serial measurements of human leucocyte elastase may be useful in the assessment and clinical management of these conditions.

Human leucocyte elastase (HLE), a neutral proteinase normally stored in the azurophil granules of the polymorphonuclear leucocytes, is released into the extracellular space during the process of phagocytosis. At physiological $\mathrm{pH}$, it cleaves many structural $^{1}$ and soluble proteins ${ }^{2}{ }^{3}$ including the components of the complement system. ${ }^{4}$ It may thus be an important mediator of inflammation and tissue damage, and increased plasma levels of human leucocyte elastase have been reported in septicaemia, ${ }^{56}$ where they correlated with clinical status, ${ }^{6}$ in leukaemia ${ }^{56}$ and in rheumatoid arthritis. ${ }^{7}$

Neutrophil infiltration is a constant histological finding in the lesions of ulcerative colitis and is frequently seen in Crohn's disease, suggesting that elastase may participate in the pathogenesis of these diseases. We report here that plasma concentrations of human leucocyte elastase measured by a new solid phase enzyme immunoassay technique ${ }^{8}$ are Address for correspondence: Professor M B Pepys, MRC Acute Phase Protein Research Group, Immunological Medicine Unit, Department of Medicine, Royal Postgraduate Medical School, Hammersmith Hospital, Du Cane Road, London W12 0HS.

Received for publication 22 February 1985 raised in patients with active inflammatory bowel disease and suggest that the circulating concentration of human leucocyte elastase may be used as a marker of disease activity.

\section{Methods}

\section{PATIENTS}

Fifty six individuals with Crohn's disease and 38 with ulcerative colitis who were all under the care of the Gastroenterology Unit, Department of Medicine, Hammersmith Hospital, were studied between November 1982 and March 1984 (Table). The diagnoses were based on standard clinical, radiological and histopathological features, the latter according to the criteria of Lockhart-Mummery and Morson. ${ }^{-11}$

\section{CONTROLS}

Healthy volunteer blood donors (180 individuals) and 20 healthy adult hospital workers were used as controls to establish the normal range of human leucocyte elastase concentration in plasma. 
Table Patients studied

\begin{tabular}{llll}
\hline & $\begin{array}{l}\text { Normal } \\
\text { controls }\end{array}$ & $\begin{array}{l}\text { Crohn's } \\
\text { disease }\end{array}$ & $\begin{array}{l}\text { Ulcerative } \\
\text { colitis }\end{array}$ \\
\hline Number & 200 & 56 & 38 \\
Age range (mean) & $18-36(34)$ & $17-83(43 \cdot 2)$ & $17-78(45 \cdot 2)$ \\
Sex ratio (M:F) & $1 \cdot 5: 1$ & $1 \cdot 1: 5$ & $2: 1$ \\
Ethnic origin & & & \\
$\quad$ Caucasian & 200 & 49 & 33 \\
Asian & - & 3 & 5 \\
West Indian & - & 4 & - \\
\hline
\end{tabular}

INVESTIGATIONS

At the same time at which blood was taken for assay of human leucocyte elastase and other variables, the level of disease activity was assessed clinically according to the criteria of de Dombal et $a l^{12}$ for Crohn's disease and Truelove and Witts ${ }^{13}$ for ulcerative colitis. On the basis of this assessment the disease in each case was classified as being active or inactive. In addition the Crohn's disease activity index $(\mathrm{CDAI})^{\mathbf{1 4}}$ was calculated for inpatients with Crohn's disease.

For determination of the circulating concentration of human leucocyte elastase, venous blood was drawn into EDTA and kept at $4^{\circ} \mathrm{C}$ until the plasma was separated by centrifugtion at $1000 \mathrm{~g}$ for 10 minutes at $4^{\circ} \mathrm{C}$. Separation was usually done within one hour of venesection and never more than three hours afterwards. The upper third of the plasma was carefully aspirated and was then stored in aliquots at $-20^{\circ} \mathrm{C}$ before assay. Because the circulating neutrophils are obviously an extremely rich source of elastase, great care in handling and separating the plasma, as described above, is essential to avoid artefactual in vitro release of the enzyme. Extensive preliminary tests on over 200 samples from patients with different diseases, including inflammatory bowel disease, established that with the present procedure, there was no correlation between plasma human leucocyte elastase and the circulating total leucocyte or neutrophil counts. The human leucocyte elastase concentration was determined by a commercial solid phase enzyme immunoassay, carried out precisely according to the manufacturer's instructions (E Merck, D-6100 Darmstadt-1, FRG; available from EM Diagnostics Ltd, Greenford, Middlesex UB6 8PN). The method $^{8}$ depends on uptake of the elastase- $\alpha_{1}$-proteinase inhibitor complex, the form in which human leucocyte elastase circulates in the plasma, by immobilised antielastase antibodies and their detection by enzymelabelled anti- $\alpha_{1}$-proteinase inhibitor antibodies. Inter and intra-assay coefficients of variation were $10 \%$ or less and the lower limit of sensitivity of the assay was $13 \mu \mathrm{g} / \mathrm{l}$.

The concentration of $\mathrm{C}$-reactive protein (CRP), the classical acute phase reactant, the serum concentrations and behaviour of which have been extensively documented in inflammatory bowel disease, ${ }^{15}$ was also measured in the same plasma samples. The technique of electroimmunoassay (lower limit of sensitivity $2 \mathrm{mg} / \mathrm{l}$ ) was used precisely as previously reported ${ }^{16}$ and no difference was detected between results obtained with EDTAplasma and with serum derived from the same blood samples in 30 different subjects. Among normal subjects $90 \%$ have CRP values less than $3 \mathrm{mg} / \mathrm{l}$ and $99 \%$ are less than $10 \mathrm{mg} / \mathrm{l}^{17}$ The erythrocyte sedimentation rate (ESR) was measured by the Westergren method ${ }^{18}$ in portions of the same samples used for C-reactive protein and human leucocyte elastase assays.

\section{STATISTICAL METHODS}

Differences between the mean human leucocyte elastase concentrations in different disease groups were sought by unpaired Student's $t$ tests and in serial studies by paired $t$ tests. As C-reactive protein values cover an extended dynamic range and are generally not normally distributed, differences between groups were sought by non-parametric tests, the Wilcoxon's rank sum test and the MannWhitney U-test. Correlation between different variables was sought using Spearman's rank correlation coefficient.

\section{Results}

PLASMA HUMAN LEUCOCYTE ELASTASE CONCENTRATION IN INFLAMMATORY BOWEL DISEASE

The human leucocyte elastase concentrations in healthy normal controls showed a near normal distribution with a mean of $55 \mu \mathrm{g} / \mathrm{l}$ and a standard deviation of 14 (Fig. 1). The normal range (2 SD about the mean) was thus established to be $27-83$ $\mu \mathrm{g} / \mathrm{l}$. Patients with active Crohn's disease and ulcerative colitis had raised human leucocyte elastase concentrations. The mean concentration in 31 cases of active Crohn's disease was $169 \mu \mathrm{g} / \mathrm{l}$, while in 23 patients with active ulcerative colitis it was 119 $\mu \mathrm{g} / \mathrm{l}$. These values were both highly significantly different from normal $(\mathrm{p}<0 \cdot 00001)$. In addition the mean human leucocyte elastase in patients with active Crohn's disease was higher than in patients with active ulcerative colitis $(p=0.013)$.

Among patients with active Crohn's disease, 13 had predominantly small bowel disease, 14 large bowel and only four had combined small and large bowel Crohn's disease. The mean human leucocyte 


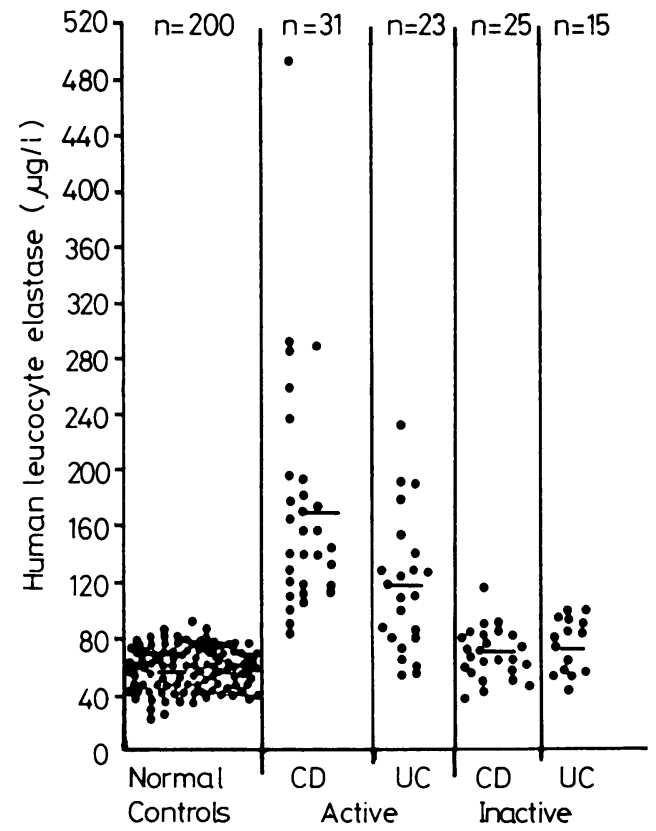

Fig. 1 Plasma HLE concentration in normals and in patients with Crohn's disease (CD) and ulcerative colitis $(U C)$. Each point represents the value in a single individual.

elastase values in these subgroups were 158,166 , and $213 \mu \mathrm{g} / \mathrm{l}$ respectively and were not significantly different from each other.

Twenty five patients with inactive Crohn's disease and 15 patients with quiescent ulcerative colitis had mean human leucocyte elastase concentrations of 69 and $74 \mu \mathrm{g} / \mathrm{l}$ respectively (Fig. 1). These values were significantly less than those seen in active Crohn's disease and ulcerative colitis $(p=0.0001$ and $p=0.0014$ respectively), but did not differ from each other. They were, however, both greater than normal $(\mathrm{p}<0 \cdot 01)$.

In 25 patients with active Crohn's disease repeat measurements of plasma human leucocyte elastase concentration were available after treatment when the disease was quiescent. There was a significant fall from a mean of $174 \mu \mathrm{g} / \mathrm{l}$ to $80 \mu \mathrm{g} / \mathrm{l}(\mathrm{p}<0.00001)$ (Fig. 2). In 15 patients with ulcerative colitis who were tested when active and in remission the mean human leucocyte elastase value fell from $132 \mu \mathrm{g} / \mathrm{l}$ to $77 \mu \mathrm{g} / \mathrm{l}(\mathrm{p}=0.00009)$ (Fig. 3).

COMPARISON OF PLASMA HUMAN LEUCOCYTE ELASTASE CONCENTRATIONS WITH OTHER LABORATORY MEASUREMENTS

As previously reported ${ }^{1516}$ the circulating C-reactive protein concentration was raised in active

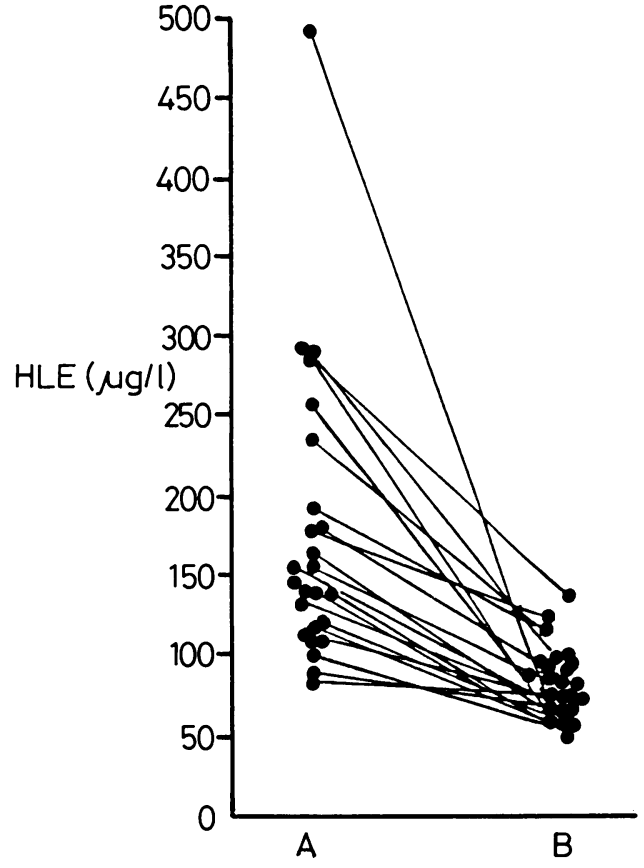

Fig. 2 Plasma HLE concentration in patients with active Crohn's disease $(A)$ and in subsequent remission $(B)$. $n=25$.

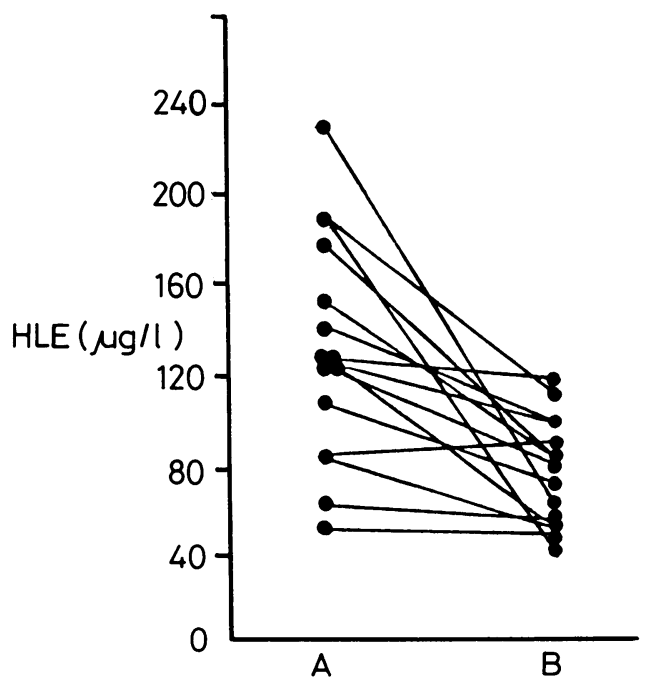

Fig. 3 Plasma HLE concentration in patients with active ulcerative colitis $(A)$ and in subsequent remission. $n=15$. 
inflammatory bowel disease, being greater in Crohn's disease (median $20 \mathrm{mg} / \mathrm{l}$, range $<2-237$ $\mathrm{mg} / \mathrm{l}, \mathrm{n}=31$ ) than in ulcerative colitis (median 6 $\mathrm{mg} / \mathrm{l}$, range $<2-110, \mathrm{n}=23)(\mathrm{p}=0 \cdot 019)$. In both groups of patients there was a significant correlation between human leucocyte elastase and C-reactive protein values: Crohn's disease, $\mathrm{R}=0.57, \mathrm{p}<0.01$ (Fig. 4) and ulcerative colitis, $\mathrm{R}=0 \cdot 37, \mathrm{p}<0.05$ (Fig. 5). In inactive Crohn's disease the median plasma CRP value was $3 \mathrm{mg} / \mathrm{l}$ and in inactive ulcerative colitis it was $<2 \mathrm{mg} / \mathrm{l}$.

The CDAI was calculated for 19 patients and it correlated significantly with their human leucocyte elastase concentrations $(\mathrm{R}=0.481, \mathrm{p}<0.005)$ (Fig. 6).

Erythrocyte sedimentation rate values were greater than normal in both groups of patients and also in patients with inactive disease. They did not correlate significantly with plasma human leucocyte elastase concentrations.

\section{Discussion}

Although the pathogenesis of inflammatory bowel disease is not understood, the presence of neutrophil polymorphonuclear leucocytes in the lesions and their known capacity for production of tissue

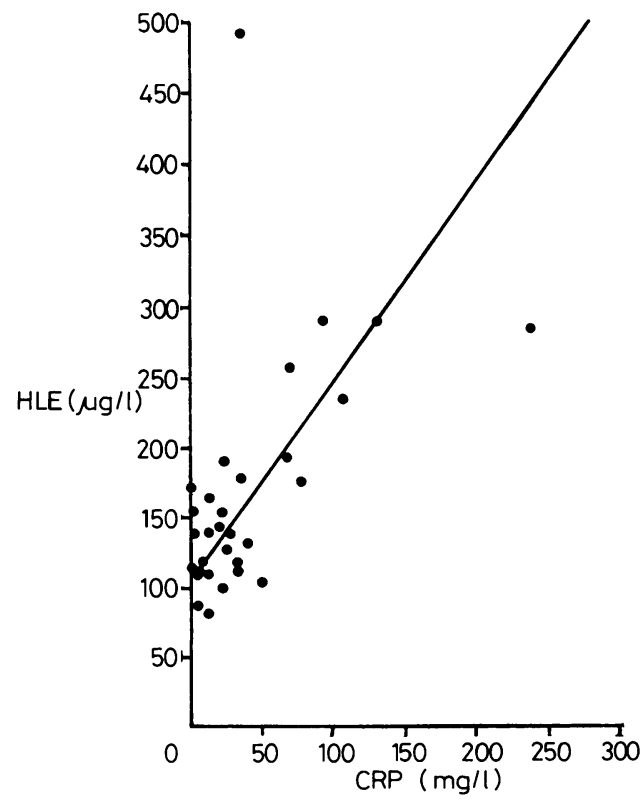

Fig. 4 Correlation between plasma HLE and CRP concentrations in patients with active Crohn's disease. $n=31, R=0.57, p<0.01$.

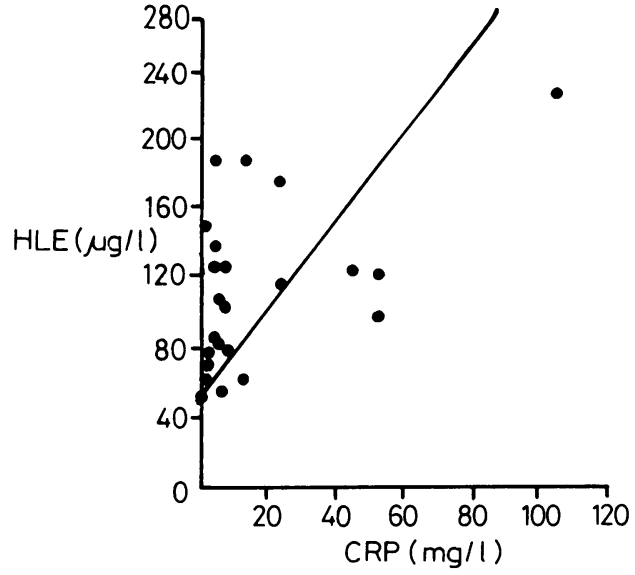

Fig. 5 Correlation between plasma HLE and CRP concentrations in patients with active ulcerative colitis. $n=23, R=0.37, p<0.05$.

injury makes them important candidates as mediators of inflammation and organ damage. Indeed there is an excellent correlation between clinical and objective assessments of disease activity in Crohn's disease and the number of autologous granulocytes excreted in the faeces. ${ }^{19}$

Information about elastase, exocytosed by neut-

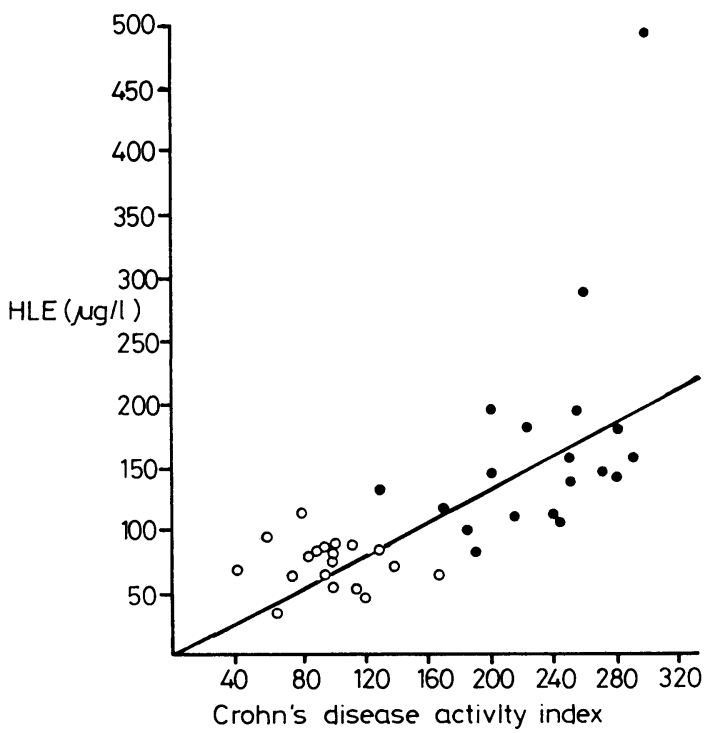

Fig. 6 Correlation between plasma HLE concentration and Crohn's disease activity index. $n=38, R=0 \cdot 66$, $p<0.0001$ for all patients; for patients with active disease (closed circles): $n=19, R=0.48, p<0.05$. 
rophils and potentially one of their most damaging products, is therefore of considerable interest. The recent advent of a simple, accessible procedure ${ }^{8}$ for estimation of the HLE- $\alpha_{1}$-proteinase inhibitor complex, in which form the bulk of the enzyme circulates in the plasma, facilitates investigation of this question. We report here that both in active Crohn's disease and in active ulcerative colitis the plasma concentration of human leucocyte elastase is markedly raised, with very little overlap into the normal range. As patients go into clinical, symptomatic remission there is a highly significant fall although the values remain slightly but significantly above normal. This may reflect the well recognised fact that histologically demonstrable inflammatory activity is frequently present even in clinical remission of inflammatory bowel disease.

Insufficient longitudinal information is available from this initial study to establish whether serial measurements of human leucocyte elastase are superior to other objective, serological indices of disease activity. The results, however, show excellent correlation between human leucocyte elastase values and simple clinical assessments of disease activity as well as with the more complex, numerical scores of the CDAI and with the objective measurements of circulation C-reactive protein concentration. In the sense that assay of human leucocyte elastase may represent direct measurement of a pathogenic mechanism, albeit only the spill over from lesions to plasma, it may prove to be a very useful new marker for disease activity.

Elastase has previously been studied in the lesions of inflammatory bowel disease. The failure of Kane and Vincenti, ${ }^{20}$ however, to detect any difference in the elastase content of the rectal biopsies from patients with active or inactive inflammatory and functional bowel disorders probably reflects the fact that they were using an assay for specific proteinase activity. Such activity is normally extremely short lived in vivo as a result of rapid formation of HLE- $\alpha_{1}$-proteinase inhibitor complexes. The inhibitor is of relatively low molecular weight and rapidly attains inhibitory concentrations in inflammatory exudates. In the present study human leucocyte elastase was detected and assayed immunochemically as the physiological enzymatically inactive proteinase-inhibitor complex and the finding of raised plasma concentrations is in agreement with the observations both by Kane and Vincenti ${ }^{20}$ and by O'Morain $e t a l^{21}$ of increased concentrations of other neutrophil markers in the lesions. Investigation of the presence of HLE- $\alpha_{1}$-proteinase inhibitor complexes in the faeces of patients with inflammatory bowel disease will be of interest, and may provide additional evidence of pathogenetic import- ance, but such studies have yet to be undertaken.

Differences between Crohn's disease and ulcerative colitis in the concentration of several serum markers have been reported. Although the early claim by Falchuk et $a l^{22}$ that serum lysozyme concentrations were higher in Crohn's disease than in ulcerative colitis and could be used for differential diagnosis, was not supported by subsequent studies, there is a general trend towards higher values in Crohn's disease. ${ }^{23-26}$ Similarly the serum concentration of C-reactive protein is usually greater in patients with Crohn's disease than in those with ulcerative colitis for any given degree of disease activity and perhaps as a consequence of the extended dynamic range of $\mathrm{C}$-reactive protein, this difference attains a high degree of statistical significance. ${ }^{15} 16$ The present findings with plasma human leucocyte elastase concentrations follow a similar, albeit less marked pattern but in view of the overlap between the two conditions, human leucocyte elastase measurements clearly do not convey any useful differential diagnostic information in individual cases.

As with other clinical laboratory correlative studies in inflammatory bowel disease ${ }^{1627}$ there are some exceptional patients in whom human leucocyte elastase is raised in the absence of symptoms and others with clinical activity but no or only a minor rise of the human leucocyte elastase value. The false negative result may arise when symptoms are largely caused by, for example, fixed fibrous obstruction rather than by inflammation, while corticosteroid therapy may, in contrast, increase feelings of well being and mask symptoms without suppressing inflammatory activity. Rather than limiting the usefulness of human leucocyte elastase assays, findings of this type suggest that knowledge of the human leucocyte elastase concentrations should be a valuable component of the assessment of disease activity in inflammatory bowel disease and in monitoring its response to therapy. Further detailed and serial studies are clearly indicated to investigate this prospect.

We are indebted to Dr T Davis and colleagues of the National Blood Transfusion Centre, Edgware, Middlesex, for the normal control specimens. This study was supported in part by MRC Programme Grant G979/51 to MBP and by E Merck, Darmstadt, FRG.

\section{References}

1 Janoff A. Human granulocyte elastase. Further delineation of its role in connective tissue damage. Am J Pathol 1972; 68: 579-92. 
2 Gramse M, Bingenheimer C, Schmidt W, Edbring R, Havemann K. Degradation productions of fibrinogen by elastase-like neutral protease from human granulocytes - characterisation and effects on blood coagulation in vitro. J Clin Invest 1978; 61: 1027-33.

3 Plow EF, Edgington TS. An alternative pathway for fibrinolysis. I. The cleavage of fibrinogen by leucocyte proteases at physiological H. J Clin Invest 1975; 56: $30-8$.

4 Johnson U, Ohlsson K, Ohlsson I. Effects of granulocyte neutral proteases on complement components. Scand J Immunol 1976; 5: 421-6.

5 Egbring R, Schmidt W, Fuchs G, Havemann K. Demonstration of granulocytic proteases in plasma of patients with acute leukaemia and septicaemia with coagulation defects. Blood 1977; 49: 219.

6 Jochum M, Duswald KH, Hiller E, Fritz H. Plasma levels of human granulocytic elastase- $\alpha_{1}$-proteinase in hibitor complex $\left(\mathrm{E}-\alpha_{1} \mathrm{PI}\right)$ in patients with septicaemia and acute leukaemia. In: Goldberg DM, Werner M, eds. Progress in clinical enzymology II. New York: Masson Publications, vol 2: 1983.

7 Schnebli HP, Christen P, Jochum M, Mallya RK, Pepys MB. Plasma levels of inhibitor bound leukocyte elastase in rheumatoid arthritis patients. In: Heidland A, Horl WH, eds. Proteinases: potential role in health and disease. London: Plenum, 1984: 345-53.

8 Neumann S, Heinrich N, Gunza G, Lang H. Enzymelinked immunoassay for elastase from leucocytes in human plasma. J Clin Chem Clin Biochem 1981; 19: 232.

9 Lockhart-Mummery HE, Morson BC. Crohn's disease (regional enteritis) of the large intestine and its distinction from ulcerative colitis. Gut 1960; 1: 87-105.

10 Lockhart-Mummery HE, Morson BC. Crohn's disease of the large intestine. Gut 1964; 5: 493-509.

11 Morson BC. Rectal biopsy in inflammatory bowel disease. New Engl J Med 1972; 287: 1337-9.

12 de Dombal FT, Burton IL, Clamp SE, Goligher JC. Short-term course and prognosis of Crohn's disease. Gut 1974; 15: 435-43.

13 Truelove SC, Witts LJ. Cortisone in ulcerative colitis: final report on a therapeutic trial. $B r$ Med J 1955; 2: 1041-4.

14 Best WR, Becktel JM, Singleton JW. Rederived values of the eight coefficients of the Crohn's disease activity index (CDAI). Gastroenterology 1979; 77: 843-6.

15 Pepys MB, Druguet M, Klass HJ, Dash AC, Mirjah $\mathrm{DD}$, Petrie A. Immunological studies in inflammatory bowel disease. In: Knight J, Porter R, eds. Immunology of the gut. Amsterdam: Elsevier/Excerpta Medica/ North Holland, 1977: 283-97.

16 Fagan EA, Dyck RF, Maton PN, Hodgson HJF, Chadwick VS, Pepys MB. Serum levels of C-reactive protein in Crohn's disease and ulcerative colitis. Eur J Clin Invest 1982; 12: 351-60.

17 Shine B, de Beer FC, Pepys MB. Solid phase radioimmunoassays for C-reactive protein. Clin Chim Acta 1981; 117: 12-23.

18 International Committee for Standardisation in Haematology. Reference Method for the erythrocyte sedimentation rate (ESR) test on human blood. $\mathrm{Br} J$ Haematol 1973; 24: 671-3.

19 Saverymuttu SH, Peters AM, Lavender JP, Pepys MB, Hodgson HJF, Chadwick VS. Quantitative faecal indium III-labelled leukocyte excretion in the assessment of disease in Crohn's disease. Gastroenterology 1983; 85: 1333-9.

20 Kane SP, Vincenti AC. Mucosal enzymes in human inflammatory bowel disease with reference to neutrophil granulocytes as mediators of tissue injury. Clin Sci 1979; 57: 295-303.

21 O'Morain C, Smethurst P, Levi AJ, Peters TJ. Biochemical analysis of enzymic markers of inflammation in rectal biopsies from patients with ulcerative colitis and Crohn's disease. J Clin Pathol 1983; 36: 1312-6.

22 Falchuk KR, Perrotto JL, Isselbacher KJ. Serum lysozyme in Crohn's disease and ulcerative colitis. $N$ Engl J Med 1975; 292: 395-7.

23 Falchuk KR, Perrotto Jl, Isselbacher KJ. Serum lysozyme in Crohn's disease. A useful index of disease activity. Gastroenterology 1975; 69: 893-6.

24 Dronfield MW, Langman MJS. Serum lysozyme in inflammatory bowel disease. Gut 1975 ; 16: 985-7.

25 Mallas E, Terry JM, Asquith P, Cooke WT. Serum lysozyme in inflammatory bowel and coeliac disease. $J$ Clin Pathol 1976; 29: 598-600.

26 Klass HJ, Neale G. Serum and faecal lysozyme in inflammatory bowel disease. Gut 1978; 19: 233-9.

27 Cooke WT, Prior P. Determining disease activity in inflammatory bowel disease. J Clin Gastroenterol 1984; 6: $17-25$. 